\section{Extensive Plexiform Neurofibroma Presenting as Clitoromegaly in Neurofibromatosis Type 1}

\author{
Tip 1 Nörofibromatoziste Kliteromegali Olarak \\ Gözlenen Ekstensif Plexiform Nörofibrom
}

Özlem Nalbantoğlu $\odot$ Gülçin Arslan $\odot$ Beyhan Özkaya $\odot$ Sinan Genç $\odot$ Behzat Özkan $\odot$

\begin{abstract}
Neurofibromatosis type 1 (NF1) is an autosomal-dominant disorder with multisystem involvement. Genitourinary involvement of neurofibromatosis type 1 is a rare condition and involvement of plexiform neurofibroma can cause painful clitoromegaly. A 9-year-old girl with neurofibromatosis type-1 was referred with clitoromegaly to our endocrinology clinic. Pelvic magnetic resonance imaging (T2W images) showed that there was an $8 \times 7 \times 13 \mathrm{~cm}$ plexiform neurofibroma in the pelvic floor and peripubic region extending to the external genitalia and progressing to the subcutaneous soft tissue. Cranial and lumbosacral magnetic resonance imaging revealed two neurofibromas in the cerebellar region and the basal ganglia. It should be taken into consideration that suspicious genitalia may develop due to infiltration of space occupying formations such as neurofibromas.
\end{abstract}

Keywords: Plexiform neurofibroma, clitoromegaly, neurofibromatosis, NF1

Öz

Nörofibromatozis tip 1 birçok sistemi tutan otozomal dominat bir hastalıktır. Nörofibromatozis tip 1'de genito-üriner sistem tutulumu oldukça nadirdir ve fleksiform nörofibrom ağrılı kliteromegaliye yol açabilir. Nörofibromatozis tip-1 tanısıyla izlenmekte olan 9 yaşında kı çocuğu, endokrinoloji kliniğimize kliteromegali şikayeti ile başvurdu. Pelvik magnetik rezonans görüntülemede (T2W görüntüleri) pelvik taban ve peripubik bölgede $8 \times 7 \times 13 \mathrm{~cm}$ boyutlarında, dış genital bölgeye uzanan ve deri altı yumuşak dokuya doğru ilerleyen pleksiform nörofibrom saptandı. Kraniyal ve lumbosakral magnetik rezonans görüntülemede serebellar bölgede ve bazal gangliyonlarda iki nörofibrom saptandı. Nörofibromlar gibi yer kaplayan oluşumların infiltrasyonuna bağlı olarak şüpheli genital yapıların gelişebileceği akılda tutulmalıdır.

Anahtar kelimeler: Pleksiform nörofibrom, kliteromegali, nörofibromatozis, NF1
Received: 15.01 .2021

Accepted: 22.02 .2021

Published Online: 03.08.2021

Cite as: Nalbantoğlu Ö, Arslan G, Özkaya B, Genç $S$, Özkan B. Extensive plexiform neurofibroma presenting as clitoromegaly in neurofibromatosis Type 1. İzmir Dr. Behçet Uz Çocuk Hast. Dergisi. 2021;11(2):215-8

Özlem Nalbantoğlu
İzmir Dr. Behçet Uz Çocuk Hastalıkları
ve Cerrahisi EAH
İsmet Kaptan Mah.
Sezer Doğan Sok. No: 11. Konak
İzmir - Türkiye
ozlemnalbantmd@yahoo.com
ORCiD: 0000-0002-0410-5761

G. Arslan 0000-0003-4506-2654

B. Özkaya 0000-0002-4161-2631

B. Özkan 0000-0002-9153-8409 S.B.Ü. Dr. Behçet Uz Çocuk Sağlığı ve Cerrahisi Eğitim ve Araştırma Hastanesi, Çocuk Endokrin Kliniği, izmir, Türkiye

S. Genç 0000-0003-2634-7515 S.B.Ü. Dr. Behçet Uz Çocuk Sağlığı ve Cerrahisi Eğitim ve Araştırma Hastanesi, Radyoloji Kliniği, izmir, Türkiye

\section{INTRODUCTION}

Clitoromegaly, which is the abnormal growth of the clitoris imitating the penile structure, is a rare condition often associated with androgen excess in sexual differentiation disorders (1-3). Although hormonal causes of clitoromegaly especially due to congenital adrenal hyperplasia (CAH) are seen more frequently, nonhormonal conditions as pseudoclitoromegaly and idiopathic clitoromegaly are other rarely seen entities ${ }^{(4)}$. Nonhormonal disorders of clitoromegaly include neurocutaneous syndromes (neurofibromatosis, and tuberous sclerosis etc.), epidermoid cyst, hemangiomas, nevus and superficial cutaneous lipoma ${ }^{(5)}$.

Neurofibromatosis, a neurocutaneous syndrome, is a progressive autosomal dominant disease which has an incidence of approximately 1 in 3000 live births (5). The NF1 gene which encodes tumor suppressor protein named neurofibromin, is located on

(c) Copyright İzmir Dr. Behçet Uz Children's Hospital. This journal published by Logos Medical Publishing.

Licenced by Creative Commons 4.0 International (CC BY) 
chromosome 17q11.2. A mutation in the gene leads to uncontrolled cell proliferation in neurofibromas. Plexiform neurofibroma (PN) which is pathognomonic of NF1 can involve any organ in the body ${ }^{(6)}$. Neurofibromatosis divides as type1 and 2. Two of the following diagnostic criteria must be detected to establish the diagnosis of neurofibromatosis type 1 (NF1): relevant family history, presence of six or more café-au-lait macules, multiple neurofibromas, Lisch nodules, tumor on the optic nerve and skeletal abnormalities ${ }^{(7)}$. Neurocutaneous nodules which are caused by the infiltration of neurofibromas may be localized on the genital region and lead to clitoromegaly. Although involvement of the external genitalia in the form of clitoromegaly is extremely unusual, differential diagnosis is necessary for distinguishing the other causes of clitoromegaly to refrain from unnecessary and exhaustive investigations ${ }^{(8)}$.

Here, we will present a patient who applied to our outpatient clinic with clitoromegaly secondary to plexiform neurofibromas.

\section{CASE REPORT}

A 10- year-old female patient presented with complaint of painful, and slowly progressive genital swelling. Her past medical history was significant for recent diagnosis of NF type 1 . Her mother and seven siblings were being followed up with the same diagnosis. On her physical examination, her weight (20 kg: <3 percentile), and height $(126 \mathrm{~cm}$ : 3-10 percentile) were measured. She had 15 café-au-lait macules and multiple neurofibromas on her skin, two of them being behind her right ear and one of them on her back. On ophthalmoscopic examination, there were Lisch nodules on both irises. She had ambigious genitalia with rigid $3 \times 1 \mathrm{~cm}$ painful clitoris. On labium majus, unlimited, rigid and painful structures which were not seemed as gonads were palpated. Urethra opened behind the clitoris and vaginal opening was intact (Figure 1). Ultrasound imaging demonstrated normal internal female genitalia including uterus, ovaries and cervix. MRI was performed on a $1.5 \mathrm{~T}$ superconducting system (EXCELART Vantage, Toshiba Medical Systems,
Otawara, Japan). We performed coronal and axial FSE T2 -weighted sequences, precontrast and postcontrast (after IV injection of $0.1 \mathrm{mmol} / \mathrm{kg}$ gadolinium) axial T1- weighted gradient echo sequences. Routine abdominopelvic MRI revealed normal adrenal glands and female internal genitalia. Pelvic MRI showed plexiform neurofibroma with dimensions of $8 \times 7 \times 13 \mathrm{~cm}$ on the pelvic floor and peripubic region extending to the external genital region and progressing into subcutaneous soft tissue. Plexiform neurofibromas demonstrated a pathognomonic target sign signal intensity. Conglomerate masses similarly exhibited bright signal intensities on T2- weighted images (Figures 2, and 3). Fat-suppressed T1-weighted axial MRI after administration of intravenous gadolinium, intense, homogeneous enhancement of the plexiform neurofibroma. Cranial MRI revealed neurofibromas in the cerebellar region and the basal ganglia, and plexiform neurofibroma in right parietal scalp (Figure 4). Karyotype analysis revealed 46 XX male syndrome.

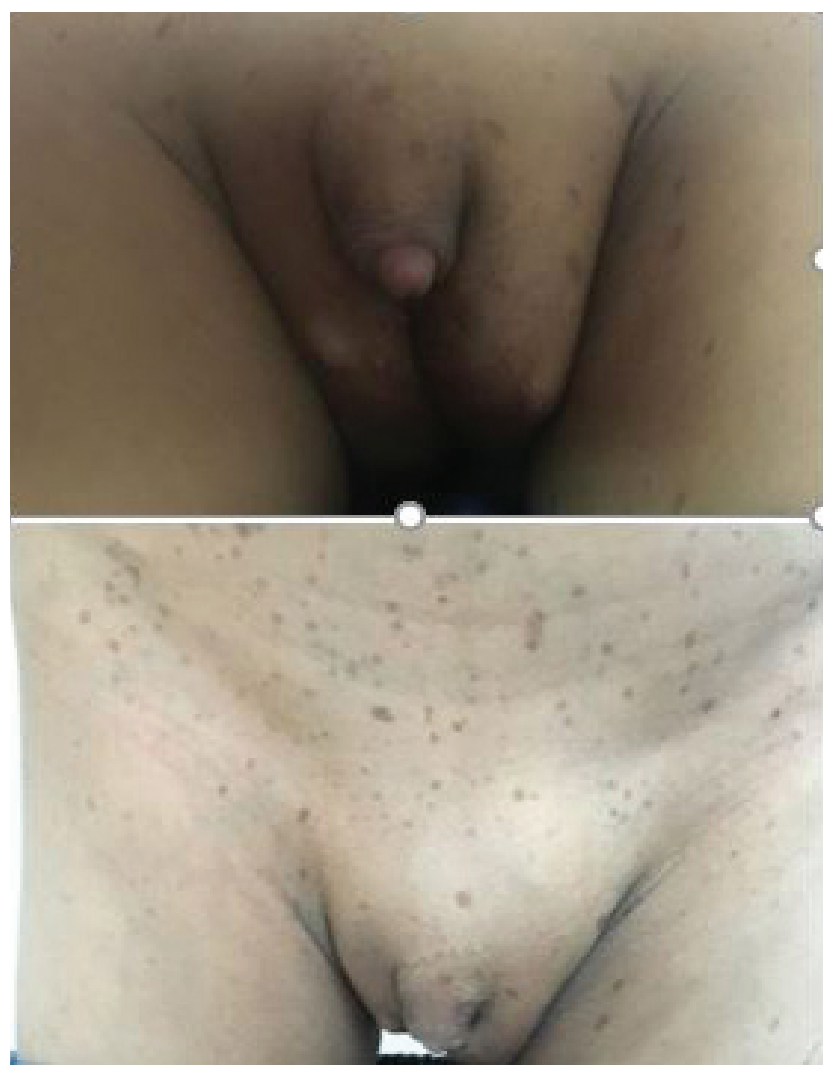

Figure 1. Neurofibromas and Clitoromegaly with pseudopenis appearance and cafe-au lait spots. 


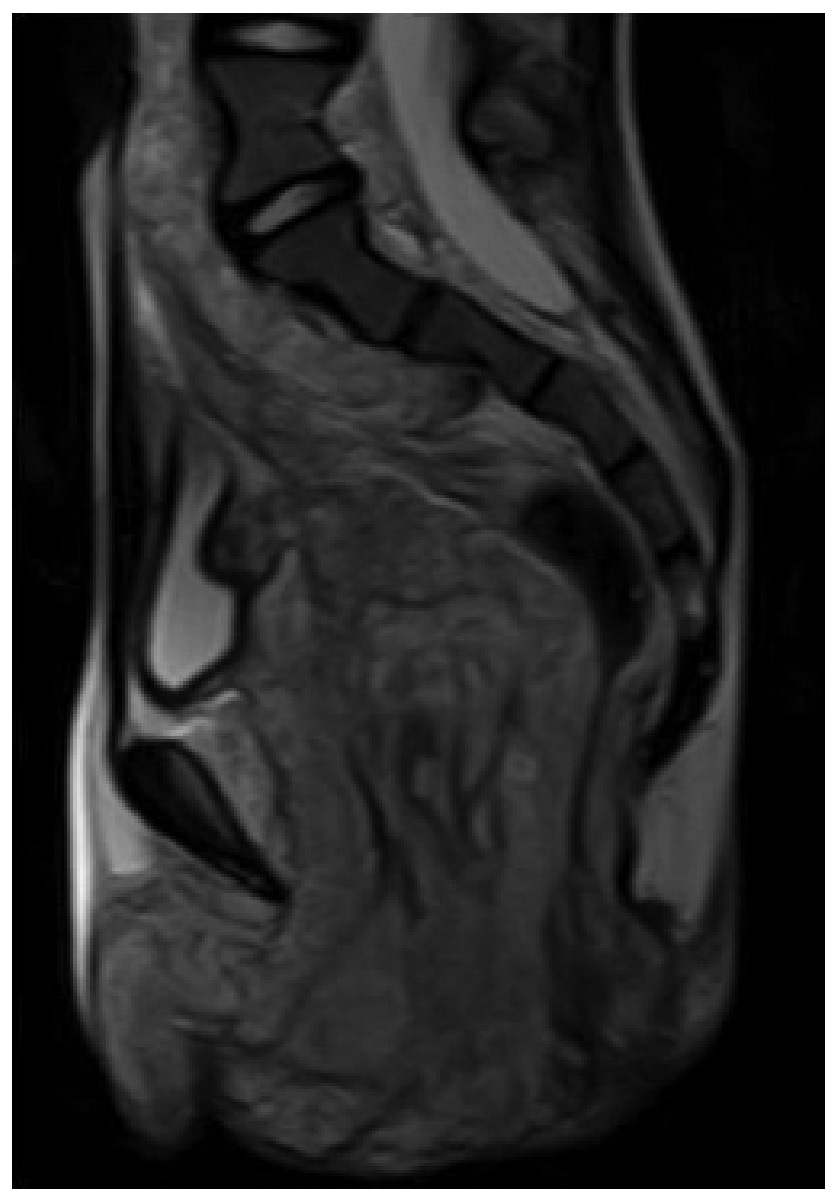

Figure 2. T2 weighted saggital image shows plexiform neurofibroma is found on the pelvic floor and peripubic region, extending to the external genital region and progressing to subcutaneous soft tissue and clitoromegaly.

Some laboratory test results were as follows: serum glucose: $86 \mathrm{mg} / \mathrm{dl}$, serum sodium: $136 \mathrm{mmol} / \mathrm{L}$, serum potassium:4.5 $\mathrm{mmol} / \mathrm{L}$, follicle stimulating hormone (FSH): $3.88 \mathrm{U} / \mathrm{L}$, luteinizing hormone (LH): $0.7 \mathrm{U} / \mathrm{L}, 17$ hydroxy progesterone (17-OH-P): 1,21 ng/ml, prolactin: $16 \mathrm{ng} / \mathrm{dl}$, adrenocorticotropic hormone (ACTH): 12.6 $\mathrm{pg} / \mathrm{ml}$, cortisol: $19.3 \mu \mathrm{g} / \mathrm{dl}$, estradiol: $15 \mathrm{ng} / \mathrm{dl}$, total testosterone: $9.5 \mathrm{ng} / \mathrm{dl}$, androstenedione: $0.608 \mathrm{ng} / \mathrm{ml}$, dehydroepiandrosterone sulfate (DHEA-S): $50.5 \mu \mathrm{g} / \mathrm{dl}$, and all these values were in normal range for this age and sex. The patient underwent nerve sparing reduction clitoroplasty and kept under follow-up for recurrence.

\section{DISCUSSION}

NF1 is an autosomal dominant progressive disorder and approximately $30-50 \%$ of patients with

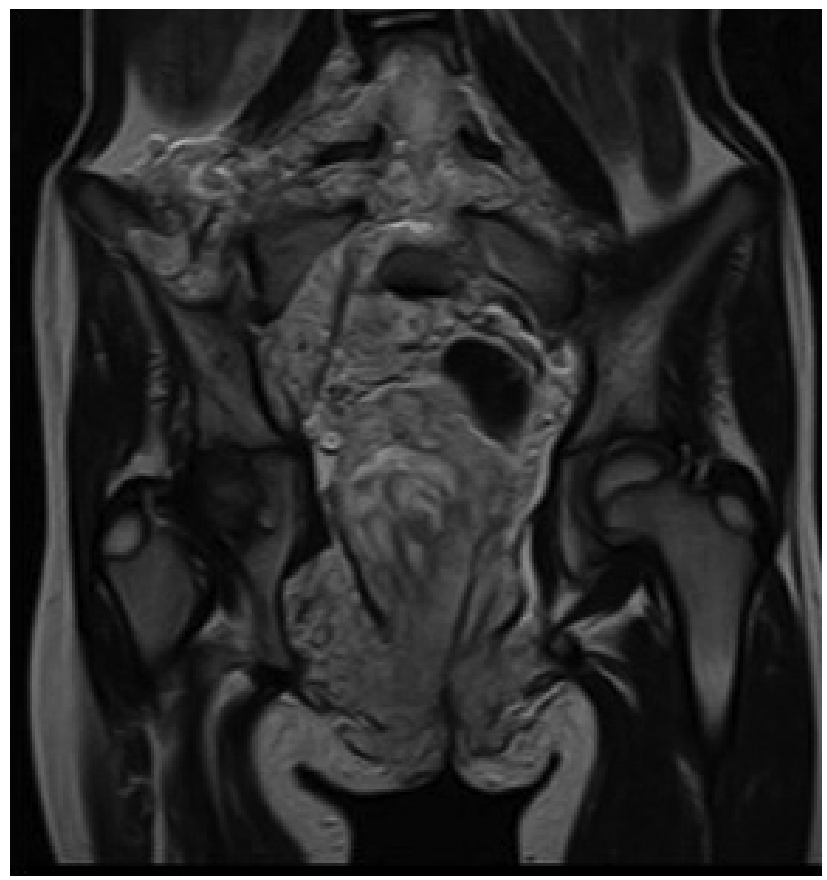

Figure 3. Coronal FSE T2 weighted image characteristic bright signal intensity on these images.

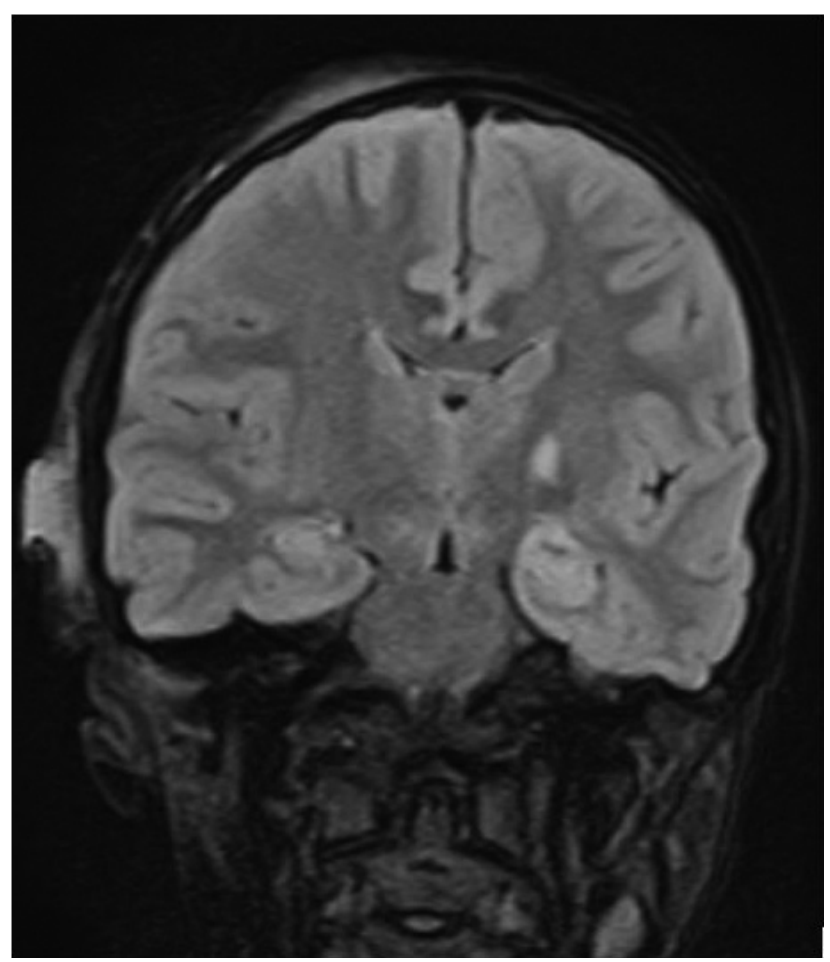

Figure 4. The MRI scan, Coronal FLAIR sequence shows typical hyperintense lesions in the basal ganglia and shows thickening with intermediate signal intensity in the right high parietal scalp. 
NF1 have plexiform neurofibromas which usually arise along the course of peripheral nerves ${ }^{(6)}$. The most frequent presenting sign in external genitalia is clitoromegaly which imitates penis in female and enlarged penis in males. Genital neurofibromas have a propensity for the contiguous involvement of the bladder and ureter. Moreover, plexiform neurofibromas have extremely rare potential to transfer malignancy ${ }^{(9,10)}$. Therefore, any child with genital neurofibromatosis should be evaluated carefully for malignant potential and involvement of bladder and ureter. Hence, magnetic resonance imaging (MRI) is an important diagnostic tool to evaluate the extension of the lesion.

Clitoral neurofibroma was firstly reported by Haddad and Jones ${ }^{(11)}$. Since then approximately 30 cases were reported. Progressive, mostly painless, increased genital size as described by our patient is the most common sign in patients with clitoral neurofibroma as described by our patients. Genitourinary signs and symptoms include frequency, urgency, hematuria, and difficulty in voiding, and other rare accompanying complaints can be seen as genital neurofibromas may be associated with lower urinary tract involvement ${ }^{(12)}$. In previous reports, genital neurofibromas were typically plexiform and surgical resection has been suggested considering the malignant potential and progressive growth ${ }^{(13)}$.

In our case, our patient had painful progressive clitoromegaly. She has been followed up with diagnosis of NF1 and also her mother and seven siblings had the same diagnosis. We performed MRI and $8 \times 7 \times 13 \mathrm{~cm}$ plexiform neurofibroma which was originated from the pelvic floor and extended into the external genital area and peripubic region from the pelvic floor was detected. Surgical resection has been chosen as treatment of the lesion because of the potential of progressive growth and risk of malignancy. The patient followed up for recurrence.

When clitoromegaly is detected, endocrinological evaluation should be done carefully. Endocrinological evaluation, family history, physical signs such as cafe au lait spots, neurofibromas which supports the diagnosis of NF provide to differentiate clitoromegaly due to NF1 from adrenogenital syndrome caused by an enzyme defect in the normal pathway of steroid biosynthesis, congenital adrenal hyperplasia, masculinizing tumors, exposure to the androgens. In all cases of clitoromegaly, hormonal, and nonhormonal etiologies should be evaluated in differential diagnosis. After surgical removal of the neurofibromas and clitoroplasty, it must be kept in mind that the patients should be follow up for recurrence of the neurofibromas.

\section{CONCLUSION}

Clitoromegaly due to plexiform neurofibromas in NF1 is rare. When painful, progressive clitoromegaly is detected in these patients, differential diagnosis of clitoromegaly due to neurofibromas due to hormonal disorders should be evaluated.

Conflict of Interest: The authors have stated that they have no conflict of interests.

Informed Consent: Informed consent of the patients was not obtained from parents.

\section{REFERANCES}

1. Kaufman-Friedman K. Hemangioma of clitoris, confused with adrenogenital syndrome: case report. Plast Reconstr Surg. 1978;62(3):452-4.

https://doi.org/10.1097/00006534-197809000-00030

2. Jesus LE, Camelier P, Bastos J, Tome AS, Dekermacher S. Clitoral Abnormalities in the Absence of Virilization: Etiology and Treatment Strategies. Urology. 2016;88:170-2

https://doi.org/10.1016/j.urology.2015.10.020

3. Geramizadeh B, Anbardar MH, Shakeri S. Clitoromegaly caused by cavernous hemangioma: A rare case report and review of the literature. Urol Ann. 2012;4(3):175-7.

https://doi.org/10.4103/0974-7796.102669

4. Bellinger MF. Feminizing genitoplasty and vaginoplasty. In: Reconstructive and Plastic Surgery of the External Genitelia 1st edition. Edited by: Ehrlich RM, Alter GJ. Philadelphia, WB Saunders; 1999:263.

5. Cost NG, Sanchez FS, Weinberg AG, Koral K, Baker LA. Neurofibromatosis presenting as painless clitoromegaly. Urol J. 2009;6(3):220-2.

6. Yesodharan D, Sudarsanan B, Jojo A, Abraham M, Bhavani N, Mathews H, et al. Plexiform neurofibroma of clitoris. J Pediatr Genet. 2017;6(4):244-6.

https://doi.org/10.1055/s-0037-1602789

7. Garg C, Agrawal A, Agrawal R, Kumar P. Neurofibroma at unusual locations: report of two cases in teenage girls. J Clin Diagn Res. 2015;9(4):ED03-4.

https://doi.org/10.7860/JCDR/2015/12082.5762

8. Karabouta Z, Rousso I, Athanassiadou-Piperopoulou F. Clitoromegaly as first presentation of a neurocutaneous syndrome in a 3-year-old girl. Clin Case Rep. 2015;3(9): 767-8

https://doi.org/10.1002/ccr3.320

9. Labardini MM, Kallet HA, Cerny JC. Urogenital neurofibromatosis simulating an intersex problem. J Urol. 1967;98(5):627-32. https://doi.org/10.1016/S0022-5347(17)62944-6

10. Thomas WJ, Bevan HE, Hooper DG, Downey EJ. Malignant schwannoma of the clitoris in a 1-year-old child. Cancer. 1989;63(11):2216-9. https://doi.org/10.1002/1097-0142(19890601)63:11 <2216::AIDCNCR2820631126>3.0.CO;2-8

11. HADDAD HM, JONES HW Jr. Clitoral enlargement simulating pseudohermaphroditism. AMA J Dis Child. 1960;99:282-7. https://doi.org/10.1001/archpedi.1960.02070030284005

12. Kearse WS Jr, Ritchey ML. Clitoral enlargement secondary to neurofibromatosis. Clin Pediatr (Phila). 1993;32(5):303-4. https://doi.org/10.1177/000992289303200511

13. Rabley A, Bayne CE, Shenoy A, DeMarco RT. Genital neurofibromatosis presenting as painful clitoromegaly. Urology. 2019;133:219-21. https://doi.org/10.1016/j.urology.2019.07.016 